SMALI WARS, BIG DATA 


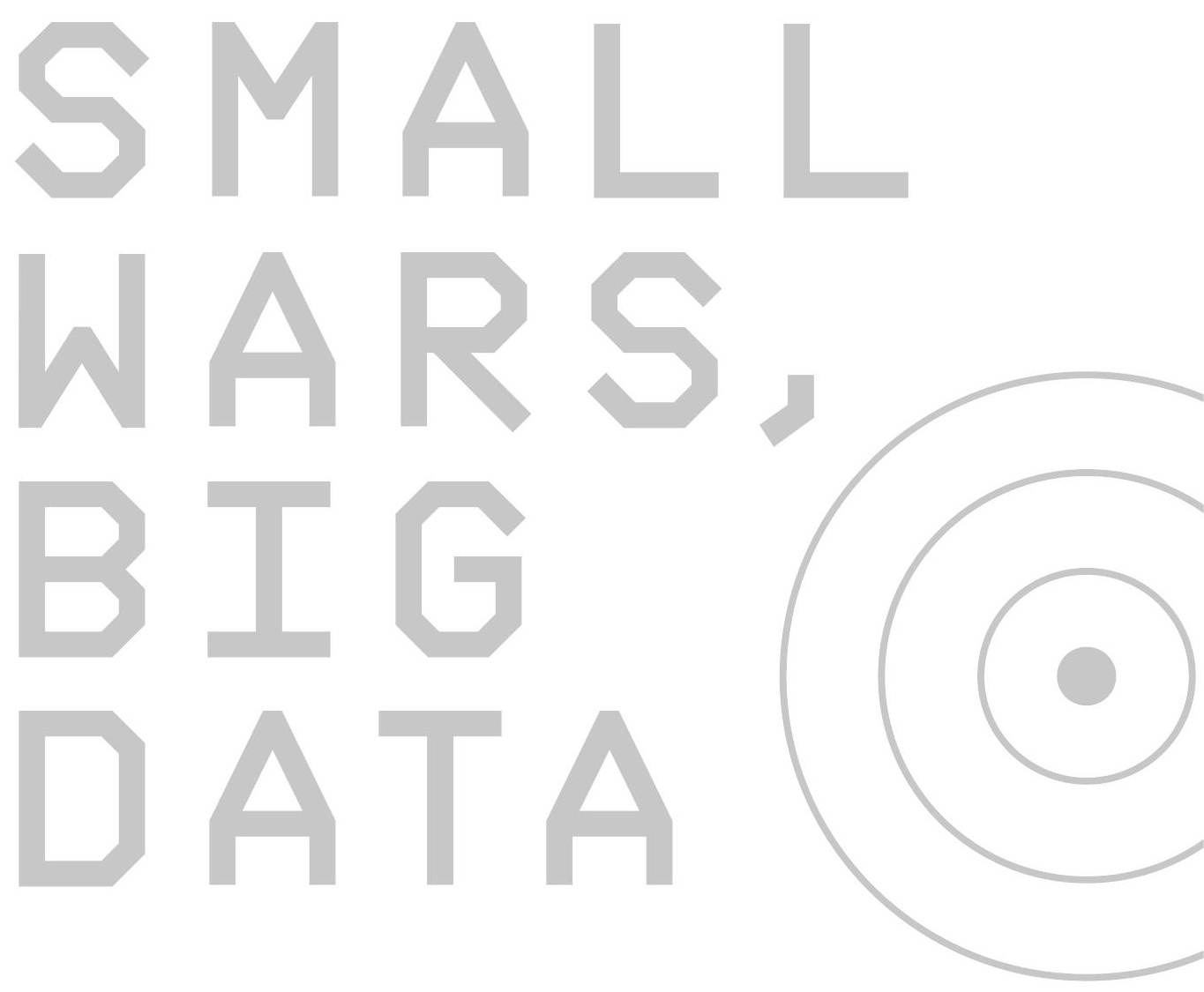

\section{THE INFORMATION REVOLUTION} IN MODERN CONFLICT

ELI BERMAN, JOSEPH H. FELTER, AND JACOB N. SHAPIRO

WITH VESTAL McINTYRE

PRINCETON UNIVERSITY PRESS PRINCETON AND OXFORD 
Copyright (C) 2018 by Princeton University Press

Published by Princeton University Press

41 William Street, Princeton, New Jersey o8540

In the United Kingdom: Princeton University Press

6 Oxford Street, Woodstock, Oxfordshire OX20 1TR

press.princeton.edu

Jacket design by Amanda Weiss

All Rights Reserved

Library of Congress Control Number 2017959003

ISBN 978-0-691-17707-6

British Library Cataloging-in-Publication Data is available

This book has been composed in Adobe Text Pro, FRAC, and Motor

Printed on acid-free paper. $\infty$

Printed in the United States of America

$10 \quad 9 \quad 8 \quad 7 \quad 6 \quad 5 \quad 4 \quad 3 \quad 2 \quad 1$ 
To our friends and comrades in the field, running the projects, and standing the watch. This is for you. 
